\title{
Are Prospective English Teachers Linguistically Intelligent?
}

\author{
Kadir Vefa Tezel ${ }^{1}$ \\ ${ }^{1}$ Abant İzzet Baysal University, Faculty of Education, Department of English Teacher Education, Turkey \\ Correspondence: Kadir Vefa Tezel, Assist. Prof. Dr., Abant İzzet Baysal University, Faculty of Education, \\ Department of English Teacher Education, TURKEY, Tel: 90-374-254-1000-1621, E-mail: vefa2000@ gmail.com.
}

Received: September 8, 2017

Accepted: September 20, 2017

Online Published: September 22, 2017

doi:10.5430/ijhe.v6n5p88

URL: https://doi.org/10.5430/ijhe.v6n5p88

\begin{abstract}
Language is normally associated with linguistic capabilities of individuals. In the theory of multiple intelligences, language is considered to be related primarily to linguistic intelligence. Using the theory of Multiple Intelligences as its starting point, this descriptive survey study investigated to what extent prospective English teachers' high school education contributed to the development of linguistic intelligence which is essential for language teachers. The data were collected, using the Teele Inventory of Multiple Intelligences. The results showed that of the seven intelligences in the inventory, linguistic intelligence was not the most dominant intelligence of the participants. Variables such as the type of high school the students graduated from, the number of years of English learning, and gender did not have any effect on the linguistic intelligence scores of prospective English teachers either. The findings indicate that a change in the criteria of selection needs to be made in admitting prospective language teachers to universities.
\end{abstract}

Keywords: Multiple intelligences, Linguistic intelligence, Prospective teachers, Teacher education, High school type, Length of language learning, Gender differences

\section{Introduction}

Communication takes place among all living creatures. Human language is a system of communication, but it is different from all non-human communication systems. Those systems relay messages only about the present time and the immediate environment whereas human language enables humans to talk about the past, the future, or even imaginary events without the limitation of physical distance. What makes humans different from the rest of all living creatures is language. Human beings have minds which is the superstructure of the brain. It is the mind that makes language possible. The mind, according to Gardner (1983), has multiple frames called intelligences - not a single one. One of those intelligences is linguistic intelligence. Language is related to linguistic intelligence. Armstrong (2009:6) defines linguistic intelligence as the capacity to use words effectively orally or in writing. Linguistic intelligence includes an individual's ability to manipulate the structure of a language, its sounds, and meanings.

In language teaching, teachers are the catalysts for learning to take place by bringing the students' minds and the target language together. At this point, the qualities of a target language teacher become important. One of those qualities is the linguistic intelligence of the English teacher. It is a tool that is essential in his trade. The higher the linguistic intelligence of the English teacher is, the better the quality of instruction and student learning will be. Like all other types of intelligences, linguistic intelligence can be developed when it is fostered. The types of high schools student attend to learn the foreign language and the length of time are two factors that may influence the development of this intelligence positively. In Turkey, there are Anatolian high schools which are a part of the state school system. These schools were initially founded to teach English at a better level to their students than regular state schools. They are considered to contribute positively to the development of the linguistic intelligence of their students. Today the types of Anatolian high schools have multiplied. In addition, students from different high school types are also eligible to become English teachers should they choose so. Thus, the role high schools may play in the development of linguistic intelligence deserves investigation. Secondly, the length of period of time one spends learning a language is a significant factor that impacts the extent of their learning.

Therefore, this study was initiated to see to what extent the linguistic intelligence of prospective English teachers had developed when they came to their universities to be trained as language teachers by looking at some factors, including the two mentioned above. 


\section{Literature Review}

Intelligence is commonly believed to be a single general mental ability. Gardner (2011) gives the traditional definition of intelligence as "a single general capacity for conceptualization and problem solving" (p. xxxi). Richards and Rodgers (2014) summarize the pre-multiple intelligences thinking regarding intelligence as a construct in the following words: "A widely accepted, but divergent, view of intelligence is that intelligence - however measured and in whatever circumstance - comprises a single factor, usually called the 'g' factor" (p. 233).

Formulating intelligence as a single general capacity necessitated its quantification in numerical terms in turn so that differences among individuals could become apparent. Gardner (1983) summarizes the efforts to that end, stating, "The chief worker in this area was the Frenchman Alfred Binet. At the beginning of the twentieth century, with his colleague Theodore Simon, Binet devised the first tests of intelligence in order to sift out retarded children and to place other children at their appropriate grade level" (p. 17). Gardner maintains that, based on his comprehensive analysis of neurological, evolutionary, and cross-cultural evidence, it would not be logical to consider intelligence as a single capacity because even idiot savants, who have serious mental problems, may display impressive abilities that surpass those of people who are labeled "intelligent", based on their traditional IQ test scores. Thus, he concluded that the common contention regarding intelligence up to that time was no longer sustainable.

Gardner in his acclaimed 1983 book starts with a review of the concept of "intelligence" and goes on to introduce his theory by devoting a chapter on each intelligence with the exception of interpersonal and intrapersonal intelligence which are discussed in chapter 8 titled "The Personal Intelligences." White (2007) outlines the evolution of the theory of multiple intelligences by referring to the works published by Gardner himself: Gardner initially identified seven specific intelligences; Linguistic intelligence, Logical-Mathematical intelligence, Spatial intelligence, Musical intelligence, Bodily-Kinesthetic intelligence, Personal intelligences: Intrapersonal and Interpersonal. In 2004, Gardner considered adding two new intelligences; Spiritual and Naturalistic. In 2006, Gardner rejected this idea and came to the decision that these intelligences were not universal and fundamental enough to be formally added (Gardner, 2006: 8).

Richards and Rodgers (2014) state, "MI theory was originally proposed by Gardner (1983) as a contribution to cognitive science. Fairly early on, it was interpreted by some general educators, such as Armstrong (1994), as a framework for rethinking school education" (p. 232). Gardner (2013) expresses the recognition his theory received in the field of education, stating, "It is important to stress that MI theory began as a psychological theory, one that also drew on brain and genetic knowledge in the early 1980s. I was surprised that the principal interest in the theory came not from psychologists but from educators. And that has remained largely true until today" (p. 2). Textbooks on multiple intelligences in education were published in Turkish as well. Two well-known Turkish books on the subject are Saban (2004) and Selçuk, Kayıll, \& Okut (2002).

In addition to general education, multiple intelligences theory found its way into the field of teaching English. Books were published and research studies were conducted. Some of those books even include considerable numbers of activities that enable interested English teachers to implement the theory in their classrooms. Three books are worth mentioning at this point. The first one is Christison (1997) in which the author proposed a list of activities that would be used for different intelligence types. The work is substantial in terms of giving teachers a taxonomy of activities on multiple intelligences. The second one is again by Christison (2005) which is a book that provides teachers with more than 160 activities, following an introduction to the theory. The third book is by Puchta and Rinvolucri (2005) who published another very practical book that contains 74 activities to be used from beginner to advanced levels and a useful teacher's quick reference guide at the end. This book utilized feedback from Howard Gardner himself during the production of the manuscript. Two influential textbooks in the field of language teaching methodology also treat multiple intelligences as a worthy topic that has relevance to teaching English. While Richards and Rodgers (2014) devote an entire chapter on multiple intelligences, Larsen-Freeman and Anderson (2011) handle the subject as part of a chapter that also deals with learning strategy training and cooperative learning.

A look at the available literature would show that ever since the introduction of the theory of multiple intelligences, the studies conducted on the subject have focused on what the theory is about and what the misconceptions about it are, even after 25 years following its introduction (Christodoulou \& Kunkel, 2009), teachers' perceptions of the traditional ways of identifying students' intelligences, the need to liberate teachers from adherence to the traditional view of intelligence, the presence or absence of the effect of the theory of multiple intelligences on students' test scores (Latham, 1997), differences between multiple intelligences instruction and traditional science instruction on elementary school students' understanding of science concepts (Özdemir, Güneysu, \& Tekkaya, 2006), how the theory is implemented in the classroom (Armstrong, 2009), and how the theory is combined with other models such 
as project-based learning to create a new and more effective instructional model (McKenzie, 2012). Only one study touched upon the theory of multiple intelligences when it examined English teachers' knowledge of innovative language learning methodologies (Kurt, 2015). Neither in-service nor pre-service language teachers and their linguistic intelligence were examined in any study in the literature.

\section{Purpose}

Noticing the gap in the professional literature, this study was initiated to find out how well the high school education system in Turkey helped prospective English teachers develop their linguistic intelligence which is an essential requisite not only for their university studies in the department of English Teacher Education but for their future teaching careers as well. To find out the extent of the development of linguistic intelligence in prospective English teachers, 4 research questions which are presented below were formulated at the outset of the study:

1. Is linguistic intelligence the most dominant intelligence of the freshman prospective English teachers?

2. Do the types of high schools the freshman prospective English teachers graduated from contribute to the development of their linguistic intelligence?

3. Does the length of the period of time for learning English contribute positively to the development of linguistic intelligence in the freshman prospective English teachers?

4. Is gender a factor that contributes to the development of linguistic intelligence in freshman prospective English teachers?

\section{Research Design and Methodology}

To find answers to the research questions, the methodology followed consisted of four components which are discussed below.

\subsection{Participants and Setting}

The participants in this study were first year students in the English Teacher Education departments of two universities in Turkey. The total number of the students was 56.15 students were male $(26,8 \%)$ and 41 were female $(73,2 \%)$. The age of the students ranged from 18 and 27 . The age average of the participants was 19.6.

The participants were graduates of 8 different high school types. 52 students (92.9\%) out of 56 were graduates of 4 different Anatolian high school types. There were only 4 students who were graduates of other high school types. Table 1 presents detailed information on the students' high school types.

Table 1. Type of High School Student Graduated from

\begin{tabular}{lllll}
\hline School Type & Frequency & Percent & Valid Percent & Cumulative Percent \\
\hline 1.Anatolian High School & 37 & 66,1 & 66,1 & 66,1 \\
2.Anatolian Teacher High School & 11 & 19,6 & 19,6 & 85,7 \\
3.Regular High School & 1 & 1,8 & 1,8 & 87,5 \\
4.Vocational High School & 1 & 1,8 & 1,8 & 89,3 \\
5.Anatolian Vocational High School & 3 & 5,4 & 5,4 & 94,6 \\
6.Religious High School & 1 & 1,8 & 1,8 & 96,4 \\
7.Anatolian Religious High School & 1 & 1,8 & 1,8 & 98,2 \\
8.Tourism Vocational High School & 1 & 1,8 & 1,8 & 100,0 \\
Total & 56 & 100,0 & 100,0 &
\end{tabular}

\subsection{The Data Collection Tool}

The Teele Inventory of Multiple Intelligences (henceforth, TIMI) (Teele, 1992) was used for data collection. TIMI is a forced choice inventory that includes 56 pictures of panda bears. The pictures are shown in 28 pairs. In each picture of the pairs, subjects see panda bears doing different activities which characterize one of the seven intelligences. Subjects choose one picture in each pair which "they feel is most like them" (Teele, 1996, p. 67). Each intelligence is represented in 8 pictures. For scoring the inventory, a scale of $0-8$ is used for all seven intelligences. At the end of scoring, the four intelligences that have the most scores are identified as that subject's dominant intelligences. 
The original seven intelligences are included in TIMI; other intelligence types proposed by Gardner later are not included in the inventory because Teele (2004) does not acknowledge them as primary intelligences. White (2007) furnishes the following information about the inventory: "The inventory currently being widely used for multiple intelligences theory is the Teele Inventory of Multiple Intelligences. This inventory is utilized for any age level because it is pictorial in nature and thus allows the subject to respond without it being necessary for them to be able to read or write. This is ideal to use with younger children, illiterate individuals, and non-English speakers" (p. 25).

Regarding the validity of the inventory, Erkan and Öztürk (2013) report that validity studies were conducted by Teele between 1992-1993 and the inventory was found to be valid. Validity studies were conducted in Turkey by different researchers as well. "The validity studies carried out in Turkey by Oklan and Elibol (2000), Göğebakan (2003), Terzioğlu (2005) and Özdemir (2006) also revealed that the inventory was valid" (Erkan \& Öztürk, 2013, p. 4).

As for the reliability of the inventory, Teele (1996) reports test-retest studies conducted to prove its reliability and continues to say that at the time of the publication of her work, the inventory was being used by "more than 1000 different public and private school settings throughout the United States, as well as seven other countries." (pp. 66-67). Erkan \& Öztürk (2013) state that Özdemir found the reliability of the inventory at the significance level of 0.01 in a 2006 study.

\subsection{Data Collection procedure}

The participants were given the inventory answer sheet and shown 28 transparencies for each pair of pictures. In order to avoid any misunderstanding, the students were told that there was no right or wrong answer and that the purpose of the study was to identify their dominant intelligences. The procedure took about 30 minutes each time the data were collected from the two groups.

\subsection{Scoring of the Teele Inventory of Multiple Intelligences}

The students' answers to the 28 items in TIMI were recoded to establish four levels to categorize their responses. The levels were established by the researcher to quantify the prospective English teachers' levels of the development of their linguistic intelligences. As there are 8 items for each intelligence in TIMI, the levels were set as follows: 1-2 answers, level 1: very low (0-25\%), 3-4 answers, level 2: low (26-50\%), 5-6 answers, level 3: mid (51-75\%), and 7-8 answers, level 4: high (76-100\%).

\subsection{Data Analysis Procedures}

The data were analyzed using statistical tests. In the analysis phase, both parametric and non-parametric statistical techniques were utilized. To answer the first research question to determine whether linguistic intelligence was the most dominant intelligence in prospective English teachers, frequency analysis was conducted. To answer the second and third research questions to find out whether the types of high school prospective teachers graduated from and the length of the period of time the students had spent to learn English had an impact on the development of their linguistic intelligence, as the sizes of the samples were not large enough and equal to group variance, the non-parametric Kruskall-Wallis test was conducted twice. As for the fourth research question, in order to determine whether the participants' gender had any effect on development of their linguistic intelligence, independent samples t-test was conducted.

\section{Findings}

To answer the first research question, following the recoding and using the established criteria, the data were analyzed using frequency analyses. Table 2 summarizes the findings.

Table 2. Dominance of Linguistic intelligence

\begin{tabular}{lllll}
\hline $\begin{array}{l}\text { Number of linguistic } \\
\text { intelligence items } \\
\text { selected }\end{array}$ & Frequency & Percent & Valid Percent & $\begin{array}{l}\text { Cumulative } \\
\text { Percent }\end{array}$ \\
\hline 1 & 19 & 33,9 & 33,9 & 33,9 \\
2 & 25 & 44,6 & 44,6 & 78,6 \\
3 & 11 & 19,6 & 19,6 & 98,2 \\
4 & 1 & 1,8 & 1,8 & 100,0 \\
Total & 56 & 100,0 & 100,0 & \\
\hline
\end{tabular}


The results in Table 2 showed that the highest linguistic intelligence score was 4 (out of 8 ) which was obtained by 1 student only. 44 students (78.6\%) were in the "very low" (0-25\%) category. 11 students (19.6\%) and 1 student (1.8\%) $(21.4 \%)$ were in the "low" (26-50\%) category. All 56 students were in these two categories. No prospective English teacher obtained an average linguistic intelligence score. Likewise, no prospective English teacher obtained a high linguistic intelligence score.

To answer the second research question, Kruskall-Wallis test was conducted and the data (Asymp. Sig. ,576) showed that there was no significant difference among the types of high schools the students graduated from in terms of their contribution to students' linguistic intelligence. In other words, no high school type positively contributed to the development of linguistic intelligence of the students. The researcher wanted to know if Anatolian high school types, particularly, would make a contribution to the development of the students' linguistic intelligence. Table 3 shows the results of the non-parametric Kruskall-Wallis test conducted to answer the second research question.

Table 3. Test Statistics ${ }^{\mathrm{a}, \mathrm{b}}$ - Type of High School Students Graduated from

\begin{tabular}{|c|c|c|c|c|c|c|c|}
\hline & $\begin{array}{l}\text { 1.Linguistic } \\
\text { Intelligence }\end{array}$ & $\begin{array}{l}\text { 2.Logical-Mathematical } \\
\text { Intelligence }\end{array}$ & $\begin{array}{l}\text { 3.Bodily-Kinesthetic } \\
\text { Intelligence }\end{array}$ & $\begin{array}{l}\text { 4.Spatial } \\
\text { Intelligence }\end{array}$ & $\begin{array}{l}\text { 5.Musical } \\
\text { Intelligence }\end{array}$ & $\begin{array}{l}\text { 6.Intrapersonal } \\
\text { Intelligence }\end{array}$ & $\begin{array}{l}\text { 7.Interpersonal } \\
\text { Intelligence }\end{array}$ \\
\hline Chi-Square & 5,693 & 8,871 & 9,395 & 10,201 & 4,501 & 10,093 & 10,210 \\
\hline Df & 7 & 7 & 7 & 7 & 7 & 7 & 7 \\
\hline $\begin{array}{l}\text { Asymp. } \\
\text { Sig. }\end{array}$ & ,576 & ,262 & ,226 & ,177 & ,721 & , 183 & ,177 \\
\hline
\end{tabular}

a. Kruskal Wallis Test

b. Grouping Variable: Type of High School Student Graduated from

To answer the third research question, firstly, the number of years the participants had been learning English was found, using frequency analysis. The analysis showed that the number of years ranged from 4 to 17 , and the average number of years the participating prospective English teachers had learned English prior to their arrival to their universities was 10.1. Mean was 10.1 and range was 13 . Table 4 below presents the visual summary of the information.

Table 4. Average Number of Years Learning English

\begin{tabular}{lllll}
\hline $\mathrm{N}$ & Minimum & Maximum & Mean & Std. Deviation \\
\hline 56 & 4,00 & 17,00 & 10,1429 & 2,41532 \\
56 & & & & \\
\hline
\end{tabular}

To answer the third research question, secondly, Kruskall-Wallis test was performed and the results showed that the length of the period of learning English did not make any contribution to the development of linguistic intelligence (Asymp. Sig. , 142). Table 5 shows that information in tabular form.

Table 5. Test Statistics ${ }^{\mathrm{a}, \mathrm{b}}$ - Length of Time of Learning English in Years

\begin{tabular}{|c|c|c|c|c|c|c|c|}
\hline & $\begin{array}{l}\text { 1.Linguistic } \\
\text { Intelligence }\end{array}$ & $\begin{array}{l}\text { 2.Logical-Mathematical } \\
\text { Intelligence }\end{array}$ & $\begin{array}{l}\text { 3.Bodily-Kinesthetic } \\
\text { Intelligence }\end{array}$ & $\begin{array}{l}\text { 4.Spatial } \\
\text { Intelligence }\end{array}$ & $\begin{array}{l}\text { 5.Musical } \\
\text { Intelligence }\end{array}$ & $\begin{array}{l}\text { 6.Intrapersonal } \\
\text { Intelligence }\end{array}$ & $\begin{array}{l}\text { 7.Interpersonal } \\
\text { Intelligence }\end{array}$ \\
\hline Chi-Square & 15,989 & 14,673 & 15,501 & 10,808 & 18,881 & 18,026 & 11,887 \\
\hline Df & 11 & 11 & 11 & 11 & 11 & 11 & 11 \\
\hline $\begin{array}{l}\text { Asymp. } \\
\text { Sig. }\end{array}$ &, 142 & ,198 &, 161 & ,459 & ,063 &, 081 & ,372 \\
\hline
\end{tabular}

a. Kruskal Wallis Test

b. Grouping Variable: Number of Years Student Has Been Learning English

To answer the fourth research question, independent samples t-test was used for analysis and the analysis (Sig. ,253) showed that gender was not a factor in terms of linguistic intelligence. Table 6 presents the results of the statistical analysis. 
Table 6. Independent Samples Test - Role of Gender

Levene's Test for Equality of

Variances

\begin{tabular}{lllllll} 
& Sig. & $\mathrm{t}$ & $\mathrm{df}$ & Sig. (2-tailed) & Mean Difference & $\begin{array}{l}\text { Dtd. } \\
\text { Difference }\end{array}$ \\
\hline 1,726 &, 195 & 1,155 & 54 &, 253 &, 03415 &, 45931 \\
\hline
\end{tabular}

\section{Discussion and Suggestions}

The results clearly indicate that after years of regular schooling, the English education prospective English teachers received prior to starting their university studies did not have any impact on the development of their linguistic intelligence. The data showed that, based on the four-level evaluation scale devised by the researcher, the highest score in linguistic intelligence was 4 out of 8 , and only one student had that score. This indicates a serious problem. One conclusion that may be reached is that the students who are being trained to become English language teachers do not possess a satisfactory level of linguistic intelligence when they start their university studies. As a matter of fact, their scores are far from any acceptable level. This result raises serious questions about the quality of the English instruction these students received during their high school education.

The lack of difference in terms of high school types compounds this finding in that even though all types of Anatolian high schools are, by definition, schools that provide higher quality English instruction in theory and on paper, this expectation does not materialize in reality as the results showed. Furthermore, of the eight types of high school the prospective English teachers graduated from, no difference was observed among the students. One cannot help but contemplate why these schools do not make any positive contribution.

The circumstances being what they are as revealed by the findings, it would be unrealistic to assume that the length of time spent learning English by the students was a decisive factor. In an environment where schools are not able to make any difference in students, it would be impractical to expect that the length of time would yield development in the students' linguistic intelligence.

The findings report clearly that in terms of developing prospective English teachers' linguistic intelligence, the high school system in Turkey did not, in any way, prepare the students who will spend the rest of their lives as English teachers to have a foundation in language which they can continue to build on during their university and subsequent studies and endeavors. This may mean that students are here mainly through their individual efforts. There may also be latent factors that are beyond the scope of this research that lead to the emergence of these negative results.

This issue requires immediate attention to English teacher education in Turkey and countries that experience the same problem. As the results of this study show, if a student spends an average of 10.1 years learning English in the state school system, and if this student aims to be an English teacher in the future, all he has left as a chance to improve his linguistic intelligence is the four-year university education that he will receive. That is a monumental expectation to be satisfied in eight semesters. The education system must immediately formulate a solution to properly educate those students who intend to become English teachers in the future before they graduate from high school. Special measures must be taken to overcome this problem. The process of teacher education must start in high school. To educate prospective English teachers in high school, truly qualified English teachers must be employed. An intensive English curriculum must be set up jointly by the Ministries of Education and higher education institutions and be strictly followed by states that experience the same problem. This program must be geared towards developing the students' oral language skills primarily, and train them extensively in the language skills, rather than burdening them with endless grammar and vocabulary teaching, followed by mechanical drilling or multiple-choice items, exercises, or tests, all of which do not contribute to the linguistic intelligence of prospective English teachers.

Finally, it must be stated that this study has two limitations: First, the data were obtained from two universities. More data from other universities may lead to more generalizable results. Thus, such studies should be conducted. Second, the data were collected from the students in two universities during their freshman year. A longitudinal study that would collect data from the same sample in order to assess to what extent education in these two universities contributes to the development of their linguistic intelligence during their sophomore, junior, and senior years would be worth undertaking. 


\section{References}

Armstrong, T. (2009). Multiple intelligencesin the classroom. ( $3^{\text {rd }}$ ed.). Alexandria, VA: Association for Supervision and Curriculum Development.

Christodoulou, J. A., \& Kunkel, C. D. (2009). Applying multiple intelligences. School Administrator, 66(2), $22-26$.

Christison, M. A. (1997). An introduction to multiple intelligences theory and second language learning.In J. Reid (ed.), Understanding learning styles in the second language classroom. EnglewoodCliffs, NJ: Prentice Hall/Regents. 1-14.

Christison, M. A. (2005). Multiple intelligences and language learning: a guidebook of theory, activities, inventories, and resources. San Francisco, CA: Alta Book Center Publishers.

Erkan, S. \& Öztürk, M. B. (2013). A study on the multiple intelligences of kindergarteners from different socioeconomic backgrounds. Procedia - Social and Behavioral Sciences 106, 250-258. Retrieved from www.sciencedirect.com. https://doi.org/10.1016/j.sbspro.2013.12.029

Gardner, H. (1983). Frames of mind: the theory of multiple intelligences.New York, NY: Basic Books.

Gardner, H. (2011). Frames of mind: the theory of multiple intelligences. (10 ${ }^{\text {th }}$ anniversary ed.). New York, NY: Basic Books.

Gardner, H. (2013). Frequently asked questions-multiple intelligences and related educational topics. retrieved February 24, 2017 from https://howardgardner01.files.wordpress.com/2012/06/faq_march2013.pdf

Kurt, M. (2015). Which methodology works better? English language teachers' awareness of the innovative language learning methodologies. Education, 135(3), 309-322.

Larsen-Freeman, D., \& Anderson, M. (2011). Techniques and principles in language teaching. (3 ${ }^{\text {rd }}$ ed.). Oxford, UK: Oxford University Press.

Latham, A. (1997). Quantifying MI's gains. Educational Leadership, 55(1), 84-85.

McKenzie, W. (2012). Intelligence quest: project-based learning and multiple intelligences. Eugene, OR. ISTE.

Özdemir, P., Güneysu, S., \& Tekkaya, C. (2006). Enhancing learning through multiple intelligences. Educational Research. 40 (2), 74-78.

Puchta, H., \& Rinvolucri, M. (2005). Multiple intelligences in EFL: exercises for secondary and adult students. Cambridge: Helbling.

Richards, J. C., \& Rodgers, T. S. (2014). Approaches and methods in language teaching. (3 ${ }^{\text {rd }}$ ed.). Cambridge, UK: Cambridge University Press.

Saban, A. (2004). Çoklu zekâ teorisi ve eğitim. (4 ${ }^{\text {th }}$ ed.). Ankara, Turkey: Nobel Publishing.

Selçuk, Z., Kayılı, H., \& Okut, L. (2002). Çoklu zekâ uygulamaları. Ankara, Turkey: Nobel Publishing.

Teele, S. (1992). Teele inventory of multiple intelligences. Redlands, CA: Sue Teele and Associates.

Teele, S. (1996). Redesigning the educational system to enable all students to succeed. NASSP Bulletin, 80, 65-75. https://doi.org/10.1177/019263659608058311

Teele, S. (2004). Overcoming barricades to reading: a multiple intelligence approach. Thousand Oaks, California: Corwin Press.

White, S. M. (2007). A comparison of multiple intelligence preferences and performance on standardized tests. (Unpublished master's thesis). Retrieved from http://rdw.rowan.edu/etd/887/ 